\title{
OPERATING PROPERTIES OF NON-WOVEN FABRIC PANEL FILTERS FOR INTERNAL COMBUSTION ENGINE INLET AIR IN SINGLE AND TWO-STAGE FILTRATION SYSTEMS
}

\section{WŁAŚCIWOŚCI EKSPLOATACYJNE WŁÓKNINOWYCH PRZEGRÓD FILTRACYJNYCH POWIETRZA WLOTOWEGO SILNIKÓW SPALINOWYCH PRACUJĄCYCH W UKŁADACH JEDNO- I DWUSTOPNIOWYCH*}

\begin{abstract}
The parameters of basic filter media used in inlet air systems of internal combustion engines of motor vehicles are presented. Performance properties of the air filters defining their basic parameters are discussed. The effects of single and two-stage filtration systems on performance, including filter medium dust capacity are presented. The methods and conditions for testing non-woven fabric filters in single and two-stage filtration systems were developed. Filter separation efficiency and flow resistance characteristic curves for non-woven fabric filters as a function of dust capacity were determined. Dust capacity of tested non-woven fabrics was determined for allowable flow resistance values. The effects of fractional composition of dust downstream of the inertial filter on reduction of dust capacity of non-woven fabrics in two-stage filtration systems were shown.The advantages including improvement in service life and reduction of wear of engine components due to use of inertial filter as the first filtration stage are presented.
\end{abstract}

Keywords: engines, performance, air cleanness, non-woven fabric filter, filter separation efficiency and filtration rate, surface wear, filter durability.

\begin{abstract}
Przedstawiono parametry podstawowych materiatów filtracyjnych powietrza wlotowego silników pojazdów mechanicznych. Omówiono właściwości eksploatacyjne filtru powietrza i określające je podstawowe parametry. Przedstawiono wpływ warunków filtracji jednostopniowej i dwustopniowejna wtaściwości eksploatacyjne, a w tym na chtonność materiału filtracyjnego.Opracowano metodykę i warunki badań włóknin filtracyjnych pracujacych $w$ warunkach filtracji jednostopniowej i dwustopniowej. Wyznaczono charakterystyki skuteczności filtracji i oporów przepływu włóknin filtracyjnych w zależności od wspótczynnika chtonności pyłu. Dla dopuszczalnej wartości oporu przepływu wyznaczonowartości współczynnika chłonności pyłu badanych włóknin. Wykazano wpływ składu frakcyjnego pyłu za filtrem bezwładnościowym na zmniejszenie wartości wspótczynnika chtonności pyłu włóknin pracujących w warunkach filtracji dwustopniowej. Przedstawiono korzyści w postaci wydlużenia czasu eksploatacji i minimalizacji zużycia elementów silnika wynikające z stosowania filtru bezwładnościowego, jako pierwszego stopnia filtracji powietrza.
\end{abstract}

Stowa kluczowe: silniki,eksploatacja, czystość powietrza, włóknina filtracyjna, skuteczność i dokładność filtracji, zużycie powierzchni, trwałość filtru.

\section{Introduction}

Modern internal combustion engines operate at higher and higher mechanical and thermal stresses and yet are required to be more reliable and durable. To meet those requirements, it is crucial to ensure high cleanliness of operating fluids, including inlet air.

High cleanliness of inlet air in the internal combustion engines of motor vehicles and machines and thus reduction of friction and improved machine life always was and still is a major operational and design issue, in particular in vehicles operating in heavy dust conditions (approx. $1 \mathrm{~g} / \mathrm{m}^{3}$ ). The conditions generally apply to special and military vehicles (tanks, land attack vehicles, self-propelled guns and special vehicles) with high-power diesel engines and maximum air demand $Q_{S i l}>1 \mathrm{~kg} / \mathrm{s}$. E.g. T-72 tank engine air supply system: (cylinder capacity $\mathrm{V}_{\mathrm{ss}}=38.8 \mathrm{dm}^{3}$ ) at $\mathrm{v}=20 \mathrm{~km} / \mathrm{h}$ on testing ground roads at air dust loading $s=1 \mathrm{~g} / \mathrm{m}^{3}$, introduces over $170 \mathrm{~kg}$ of dust at the distance of $1000 \mathrm{~km}$. Passenger car engines $\left(\mathrm{V}_{\mathrm{ss}}=1.5 \mathrm{dm}^{3}\right)$ at $60 \mathrm{~km} / \mathrm{h}$ on surfaced roads $\left(s=10 \mathrm{mg} / \mathrm{m}^{3}\right)$ introduces over $0.6 \mathrm{~kg}$ of dust at the distance of 20 thousand kilometres. The data shows, that the air filters used in special and passenger vehicles must not have the same design and operate in the same way.

Thus, all trucks and special vehicles are fitted with two-stage inlet air filtration system, where the first stage is an inertial filter and the second stage is a paper filter element. Commonly used paper filter elements feature high filter separation efficiency and low dust capacity $\left(k_{m}=(200 \div 240) \mathrm{g} / \mathrm{m}^{2}\right)$. If the paper filter element is subject to the dust downstream of the inertial filter, its dust capacity is reduced almost four times [10].

Modern production technologies of non-woven fabrics allowed them to be more commonly used as inlet air filter media in motor vehicle engines. Based on the scant data that are available from non-woven fabric manufacturers, the fabrics show significantly higher dust capacity compared to filter papers $k_{m}=(450 \div 500) \mathrm{g} / \mathrm{m}^{2}[30]$. No data

(*) Tekst artykułu w polskiej wersji językowej dostępny w elektronicznym wydaniu kwartalnika na stronie www.ein.org.pl 
are available on separation efficiency, filtration rate and durability of non-woven fabric filter elements, thus relevant tests are required.

\section{Contaminants in air and effects on engine's service life}

Free air supplied to the internal combustion engines of motor vehicles contains high quantities of the following contaminants $[4,5,23]$ :

- natural - over $85 \%$ of total contaminants (dust, plant spores, bacteria, salts and gases, e.g. carbon monoxide, sulphur dioxide, sulphur trioxide),

- mineral dust from motor vehicle traffic or wind - road dust,

- exhaust gases from motor vehicles (dust, carbon black, lead compounds, heavy hydrocarbons, particulate matter and gases) [4, 23],

- dust emission by motor vehicles due to wear of friction lining in brakes and clutch plates, tires and pavement [5]

- industrial.

Dust particles can be classified by size [4]:

- total dust - mixture of small solid particles (suspended in the air) standard size $<300 \mu$ m,suspended dust PM10 - standard size $<10 \mu \mathrm{m}$,

- fine dust PM2.5 - standard size $<2.5 \mu \mathrm{m}$,

- nanoparticles PM1 - standard size $<1 \mu \mathrm{m}$.

Motor vehicles are subject to contaminants, which introduced with air to both piston and turbine engines will result in increased wear of engine components and thus limit their reliability and durability. The most common contaminants affecting machines is the road dust, raised by moving motor vehicles or wind, and introduced with air to engine cylinders. Most naturally occurring dusts, including road dust are polydisperse dusts with different physical and chemical properties. Free air includes contaminants with size composition from $(0.001 \div 1000) \mu \mathrm{m}$. Air dust loading, defining contaminant content (in grams or milligrams) in one cubic meter of air depends on many factors: surface type, climatic conditions, drive system, height, soil type and industrial plant type. Fig. 1 shows air dust loading as a function of operating conditions [2].

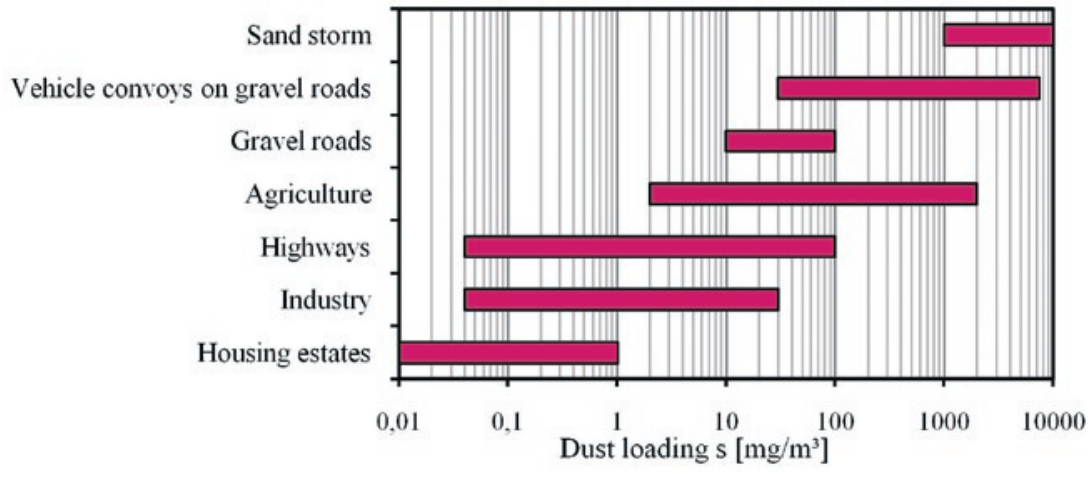

Fig. 1. Air dust loading as a function of operating conditions [2]

Air intakes of internal combustion engine intake systems draw in dust $<d_{z}=(80 \div 100) \mu \mathrm{m}$ with air. Some contaminants that enter the engine cylinders via air supply system are combusted, some are removed with the exhaust gases, and some, mostly the mineral dust (approx. $(10 \div 20) \%$ settle at the cylinder sleeve walls and are mixed with oil to forms abrasive paste. The dust on the cylinder sleeves enbetween wear $Z$ and ratio $h_{\text {min }} / d_{z}$ [12] ters between the mating surfaces (piston - rings - cylinder) and results in premature wear. During piston movement into the bottom dead centre, the dust with oil is removed to the oil sump, and via the oil lines distributed to all lubricated engine components also resulting in premature wear.

Numerous studies on the effects of contamination of operating fluids on piston engine components wear show that the dust grains with the size corresponding to the minimum thickness of the oil film between mating surfaces cause the highest wear (Fig. 2) [1, 12, 13].
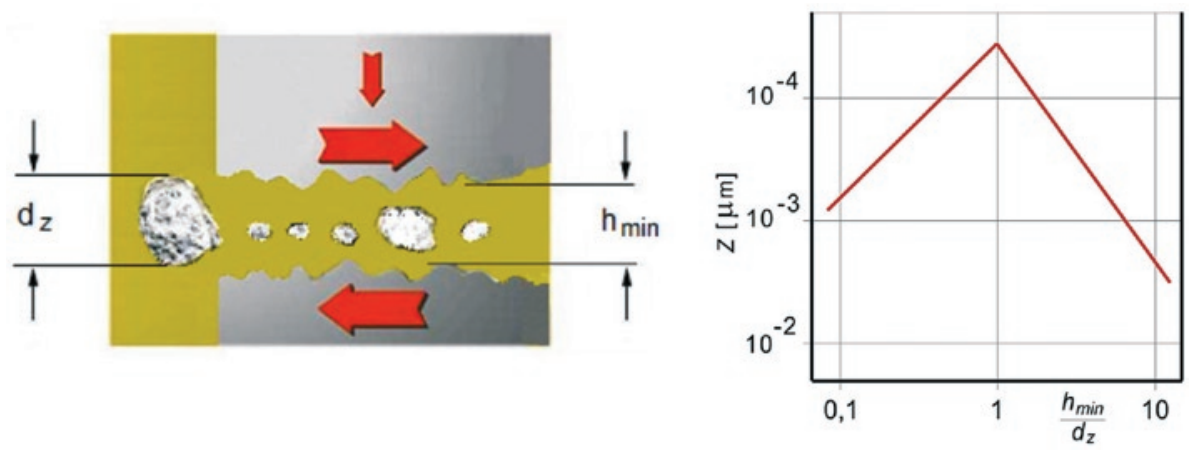

Fig. 2. The effects of the oil film thickness on wear: a) solids acting on the friction pairing, b) relationship

Oil film thickness is not constant but varies depending on the engine operating conditions, mainly its load. Oil film thickness between piston, rings and cylinder is determined by the piston speed, oil viscosity and engine load and its maximum value between the dead centres is between $(0.3 \div 7) \mu \mathrm{m}[7,12,13]$. At the dead centres, the piston speed is reduced to zero, which is one of the reasons the oil film thickness is reduced or even eliminated completely, thus resulting in increased wear [7, 13, 18, 19].

The dust particle hardness, depending on its chemical composition also affects the wear rate of mating engine components. The main component of the road dust drawn in with air is silica, with total content in the dust mass of up to $90 \%$. Silica particle hardness in Mohs' scale of hardness is 7, i.e. more than the hardness of components used in the internal combustion engine design. An example of a premature wear of engines in dump trucks used for sand transport, with mileage of approx. $(30 \div 40)$ thousand kilometres, due to premature wear of piston, rings and cylinder are shown in [26].

\section{Air filter performance parameters}

For the air filter to clean inlet air in motor vehicle engines it must feature specific properties, determined by the following parameters: separation efficiency, flow resistance and filtration rate [27].

Filter separation efficiency $\varphi$ determines filter capacity for qualitative and quantitative retention of particles in the air stream. It is mainly determined as a ratio of the test dust mass $m_{P F}$ retained by the filter to the test dust mass $m_{P D}$ introduced to the filter in the air stream in a unit of time:

$$
\varphi=\frac{m_{P F}}{m_{P D}} \cdot 100 \%
$$

Flow resistance $\Delta p_{f}$ is a total pressure difference measured directly at the filter inlet $p_{c 1}$ and the filter outlet $p_{c 2}$ :

$$
\Delta p_{f}=p_{c 1}-p_{c 2}[\mathrm{kPa}]
$$


In special cases, if the inlet and outlet line are at the same level and have the same diameter $D_{1}=D_{2}$, and thus the air flow rate is identical, the flow resistance is expressed as the difference in static pressures as:

$$
\Delta p_{f}=\Delta p_{s}=p_{s 1}-p_{s 2}[\mathrm{kPa}] .
$$

Filtration rate is a minimum dust particle size $d_{z \min }[\mu \mathrm{m}]$ retained by the filter for a specific air volume or a maximum dust particle size $d_{\text {zmax }}$ downstream of the filter.

Dust capacity $k_{m}$ is a ratio of the total dust mass $m_{C w F}$, retained by the filter element at specific $\Delta p_{\text {fdop }}$ value to active surface area of the filter paper $F_{w}$ at uniform dust distribution along the entire active surface area of the filter paper $F_{w}$ :

$$
k_{m}=\frac{m_{C w F}}{F_{w}}, \mathrm{~g} / \mathrm{m}^{2}
$$

Performance of the panel filters used in the inlet air systems of motor vehicle engines depends on the following parameters: air flow rate, dust and filter layer structure. In practice, the air filter performance is usually determined as a function of a single parameter in laboratory conditions, using standard test stands and standard tests with test dust.

In two-stage filters in "multi-cyclone - porous panel filter" configuration, the filter medium is subject to dust, which downstream of the inertial filter (multi-cyclone) shows different size distribution compared to the dust in the inlet air. Depending on the flow conditions of the aerosol inside the cyclone, clean air (cyclone outlet air) contains dust particles $<(15 \div 30) \mu \mathrm{m}$. It is both referenced in the literature [1, $16,17,22]$ and result from the single cyclone tests carried out by the authors. The filter element in serial configuration downstream of the multi-cyclone is affected by smaller dust particles. Single-stage filter draws in significantly larger dust particles, up to $80 \mu \mathrm{m}$. Thus, the filtration processes in both the former and the latter case can differ. To design a two-stage filter element, the properties of a filter medium corresponding to the operating conditions of the second stage air filter must be known. The performance data can be obtained by experimental tests, although special methods are required to ensure suitable operating conditions of the second stage filtration.

\section{Characteristics of inlet air filter media}

The most common air filters used in motor vehicles and machines are panel filters, classified by filter medium as surface filters, depth filters and surface-depth filters.

Filter papers (surface-depth medium) are the most commonly used filter media for filtration of operating fluids in motor vehicles. Filter medium manufacturers provide data on some parameters only. Since the filter paper manufacturing companies use different methods to determined those parameters, it is sometimes difficult to compare available data. In general, the filter papers are characterized by the following parameters $[8,11,14]$ :

- filter separation efficiency up to $\varphi=99.99 \%$,

- basis weight $-(115 \div 240) \mathrm{g} / \mathrm{m}^{2}$,

- bed thickness $-(0.3 \div 0.9) \mathrm{mm}$,

- pore size $-(40 \div 95) \mu \mathrm{m}$,

- fibre diameter $-(10 \div 20) \mu \mathrm{m}$,

- dust capacity - up to $(200 \div 240) \mathrm{g} / \mathrm{m}^{2}$,

- flow resistance,

- air permeability.

In the available national and foreign literature, more and more information are available on basic properties of filter papers with added nano-fibres used as inlet air filters in internal combustion engines of heavy-duty vehicles $[11,14,15]$. The data on filter separation efficiency, filtration rate and dust capacity are available in the literature, but not always include the conditions used to determine these properties. In study [11], mass of dust retained by the filter paper and filter paper with nano-fibres is specified at the point the flow resistance of $\Delta p_{w}=7.5 \mathrm{kPa}$ and air flow rate of $1360 \mathrm{~m}^{3} / \mathrm{h}$ are reached. The element made of PA1885 filter paper, at the point of reaching flow resistance of $\Delta p_{w}=7.5 \mathrm{kPa}$ have retained $2415 \mathrm{~g}$ of dust, whereas the same paper filter with a layer of nano-fibres have retained over $50 \%$ more dust, i.e. $3770 \mathrm{~g}$ in the same time period. No surface area of filter medium is specified, and thus no filtration speed and dust capacity can be determined. In study [14], dust capacity of filter paper $\left(k_{m}=28 \mathrm{~g} / \mathrm{m}^{2}\right)$ and paper with nano-fibre layer $\left(k_{m}=78 \mathrm{~g} / \mathrm{m}^{2}\right)$ is determined using AC Fine test dust $\left(d_{z \max }=80 \mu \mathrm{m}\right)$. Dust capacity of the same filter media but using sodium chloride particles (dimensions up to $d_{z}=0,4 \mu \mathrm{m}$ ) is $k_{m}=4 \mathrm{~g} / \mathrm{m}^{2}$ and $k_{m}=21 \mathrm{~g} / \mathrm{m}^{2}$, respectively. No conditions (flow resistance) at which the dust capacity was determined were specified. The results for filter paper with nano-fibre layer and AC Fine test dust showed almost twofold increase in dust capacity, and in case of sodium chlorine, the dust capacity increased almost four times. Dust capacity of filter paper determined using very fine dust $\left(d_{z \max }=0.4 \mu \mathrm{m}\right)$ was seven times lower compared to large diameter dust $\left(d_{\text {zmax }}=80 \mu \mathrm{m}\right)$.

The basic filter medium (depth filter) used in air filters for motor vehicles is a synthetic non-woven fibre. Fibrous woven fabrics feature pore size distribution which is easy to determine and filter separation efficiency, which is easy to adjust by simply changing the spinning parameters. The media allow easy cleaning due to the surface nature of filtration. Woven fabric filters are made of a single type of fibres, different types of fibres or multiple layers of fibres.

Non-woven fabric filters feature higher porosity and thus higher air permeability (lower flow resistance). They also achieve higher filter separation efficiencies, and due to even mass distribution of retained dust at the entire material depth may also achieve higher dust capacities. Random fibre layers are formed by bonding or stitching (mechanical) [6].

The development of fibre forming methods (melt-blown, electrospinning) and low production costs have contributed to more common use of non-woven fabrics as filter medium of panel filter elements in motor vehicles, industrial plants and sanitary plants [6].

Limited publications are available including the test results for nonwoven fabrics and dust particle size corresponding to the size of dust particles drawn in by the air filters of motor vehicles $\left(d_{z \max }=80 \mu \mathrm{m}\right)$.

Non-woven fabric tests are carried out on standard test stands, where the tested non-woven fabric forms a flat section enclosed in a tight container. Air filter elements are made of pleated filter medium sheets, both in case of paper filters and non-woven fabric filters. Commonly used test methods does not allow for the effects of filter medium shape on achieved filter separation efficiency and the dust capacity values. Due to air flow, pleated non-woven fabric filters can undergo deformation and deflection, which affect the conditions in which the filter cake is formed and thus affect filter separation efficiency and flow resistance [20].

Filter separation efficiency data available in the literature for fibrous filter media mainly apply to initial separation efficiency. There are limited data available on the characteristics of filter separation efficiency and flow resistance of non-woven fabric filters as a function of retained dust mass. Filter separation efficiency data are sometimes presented as a function of time, without specifying the test conditions (dust loading, flow rate, surface area or filtration velocity). The tests allow to compare different types of non-woven fabrics, although do not give any information on dust capacity, required to determine the service life of a material in specific conditions [21].

In the available studies on non-woven fabric filters, the most common characteristics involve the effects of selected non-woven fabric 
parameter (density, fibre packing density) or aerosol (grain size, filtration velocity) on filter separation efficiency $[6,21]$. Some sources give the dust capacity of non-woven fabrics, but the values are discrepant. In study [28], the dust capacity of non-calendered non-woven fabric with a thickness of $3.2 \mathrm{~mm}$, determined at a flow rate of $0.3 \mathrm{kPa}$ is $k_{m}=(54.5 \div 89.3) \mathrm{g} / \mathrm{m}^{2}$, whereas the dust capacity for identical calendered fabric is $k_{m}=(85.5 \div 112.3) \mathrm{g} / \mathrm{m}^{2}$. In study [8], the dust capacity of a multi-layer non-woven fabric filter is $k_{m}=(900 \div 1100) \mathrm{g} / \mathrm{m}^{2}$, without specifying the flow resistance used to determine the dust capacity. As per study [30], the dust capacities of non-woven fabric filters exceed $(400 \div 480) \mathrm{g} / \mathrm{m}^{2}$, although no information on test conditions and test dust used are given.

Filter separation efficiency of non-woven fabric filters can be improved by wetting the fibres with oil to ensure more durable bond between the particles and the fibres to limit re-emission and reduction of filter separation efficiency. Wetting the fibres with oil also reduces the intensity of flow resistance increase as a function of dust mass retained by the filter. As per study [24, 25] wetting the fibres with

oil have reduced the intensity of flow resistance increase by half at aerosol flow rate of $0.11 \mathrm{~m} / \mathrm{s}$.

The parameters of selected types of non-woven fabric filters manufactured by Korea Filtration Technologies Co. [29] are shown in Table 1, whereas parameters of non-woven fabric filters manufactured by Retop Fibre [30] are shown in Table 2.

Despite high filter separation efficiency (over 99\%) and high dust capacity, the non-woven fabric filters are rarely used in inlet air filtration systems in passenger motor vehicles.

Trucks and special vehicles usually operating in high dust loading conditions, are usually fitted with two-stage filtration systems that guarantee long periods between maintenance.The reasoning behind using two-stage filters consists in preliminary separation of large dust particles in the inertia filter and leaving small dust particles in the air $d_{z}<(20 \div 35) \mu \mathrm{m}$ and separation of smaller particles $d_{z}=(2 \div 5) \mu \mathrm{m}$ in the panel filter (usually paper filter element with suitable surface area).

The service life of the air filtration systems in engines until the permissible flow resistance value (maximum air flow resistance for specific engine type is determined by the manufacturer and corresponds to $3 \%$ decrease in motor power) is reached is much longer than for the panel filter itself in the same dust loading conditions. (Fig. 3). Permissible flow resistance for diesel engines used in trucks and special vehicles is $(5 \div 7) \mathrm{kPa}$.

No structural solutions for multi-stage air filters using non-woven fabric filters are available for trucks and special vehicles. It is due to lack of sufficient knowledge on non-woven fabric filter parameters, in particular dust capacity determined in two-stage filtration conditions. Use of nonwoven fabrics in inlet air filters in truck engines may significantly reduce the maintenance frequency. The dust capacity of the filter medium in two-stage filtration conditions must be known to design a two-stage air filter. The values in the available literature are given for the paper filters only.

The study shows empirical assessment of filter separation efficiency, dust capacity and flow resistance of selected non-woven fabrics for operating conditions specific to off-road vehicles.

\section{Purpose, test methods and con- ditions}

The purpose of the study was to determine the operating properties of two types of non-woven fabric filters in a single and

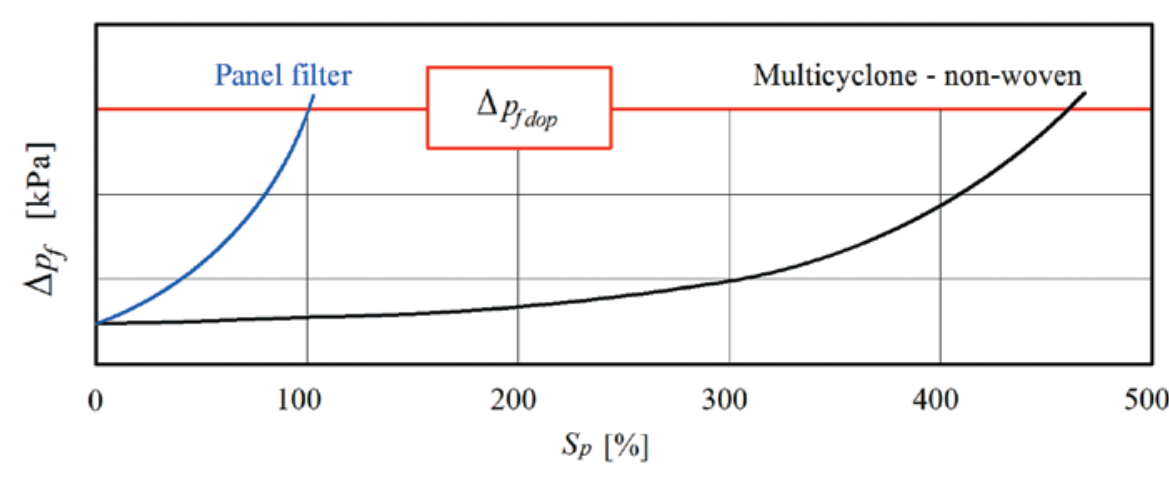

Fig. 3. Flow resistance of the single-stage air filter (porous panel filter) and the two-stage air filter in "multi-cyclone - porous panel filter" configuration depending on vehicle duty S [10]. two-stage filtration system at specific filtration velocity and dust removal rate by ejection from the multi-cyclone's settling tank.

The first stage involved determining the following characteristics: filter separation efficiency and flow resistance of two types of non-woven fabric filters operating in conditions corresponding to the second filtration stage, depending on the dust capacity as:

- filter separation efficiency $\varphi_{w 2}=f\left(k_{m 2}\right)$,

- flow resistance $\Delta p_{w 2}=f\left(k_{m 2}\right)$.

The scope of tests for the second stage involved determination of the following characteristics: filter separation efficiency and flow resist- 
Table 3. $A C-301$ and BWF-O2 E200B non-woven fabric filter parameters

\begin{tabular}{||l|c|c|c||}
\hline \multirow{2}{*}{\multicolumn{1}{|c|}{ Parameter }} & \multirow{2}{*}{ Unit } & \multicolumn{2}{c|}{ Value } \\
\cline { 3 - 4 } & & AC-301 & BWF-02 E200B \\
\hline Basis weight & {$\left[\mathrm{g} / \mathrm{m}^{2}\right]$} & $210 \pm 10 \%$ & $200 \pm 15$ \\
\hline Thickness & {$[\mathrm{mm}]$} & $2.34 \div 2.86$ & $2.00 \pm 0.1$ \\
\hline Air permeability & {$\left[\mathrm{dm}^{3} / \mathrm{m}^{2} / \mathrm{s}\right]$} & $800 \div 1100$ at $120 \mathrm{~Pa}$ & $>2300$ at $200 \mathrm{~Pa}$ \\
\hline Tensile strength & {$[\mathrm{N} / 50 \mathrm{~mm}]$} & $>98$ & - \\
\hline Bending strength & {$[\mathrm{N} / 30 \mathrm{~mm}]$} & $1.47 \div 2.94$ & - \\
\hline Flow resistance & {$[\mathrm{Pa}]$} & - & $120 \div 130$ \\
\hline Components & - & - & Polyester $100 \%$ \\
\hline
\end{tabular}

ance of a non-woven fabric in single-stage filtration system for the fabric that showed better performance in the first stage.

The tests covered two filter elements made of non-woven fabrics available in Poland (Table 3). Non-woven fabric names are given in brackets.

- two-layer AC-301 (AC) non-woven fabric by Korea Filtration Technologies Co.,

- one-layer BWF-02 E200B (B2) non-woven fabric by EkoKarpaty.

Filter elements with tested non-woven fabrics were made based on paper air filter elements for trucks available in serial production. Surface area of non-woven fabric was determined at permissible filtration velocity $[1,8]$ :

$$
v_{F d o p}=\frac{Q_{G}}{3600 \cdot F_{w}}[\mathrm{~m} / \mathrm{s}]
$$

where: $Q_{G}$ - volume flow ratio for air downstream of the filter element $\left[\mathrm{m}^{3} / \mathrm{h}\right]$, see [3], $F_{w}-$ active surface area of filter medium $\left[\mathrm{m}^{2}\right]$.

Main stream value is $Q_{G}=600 \mathrm{~m}^{3} / \mathrm{h}$. Ejection dust removal system with an air stream $Q_{S}$ (value determined based on the following equation for the specific suction rate $m_{0}=10 \%$ ) was used to remove dust from the multi-cyclone's settling tank:

$$
Q_{S}=Q_{G} \cdot m_{0}
$$

Assuming the permissible filtration velocity as for the filter papers $v_{F d o p}=0.08 \mathrm{~m} / \mathrm{s}$, surface area of the non-woven fabric filter is $F_{w}=2.0 \mathrm{~m}^{2}$.

The tests were carried out at constant air stream flow through the filter $Q_{G}=600 \mathrm{~m}^{3} / \mathrm{h}$ and suction stream $Q_{s}=60 \mathrm{~m}^{3} / \mathrm{h}$, at assumed dust

a)

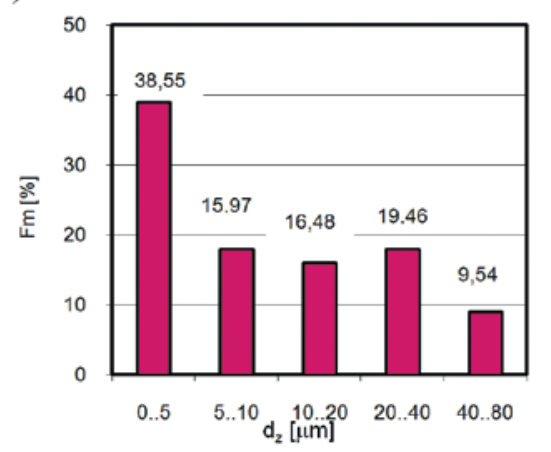

b)

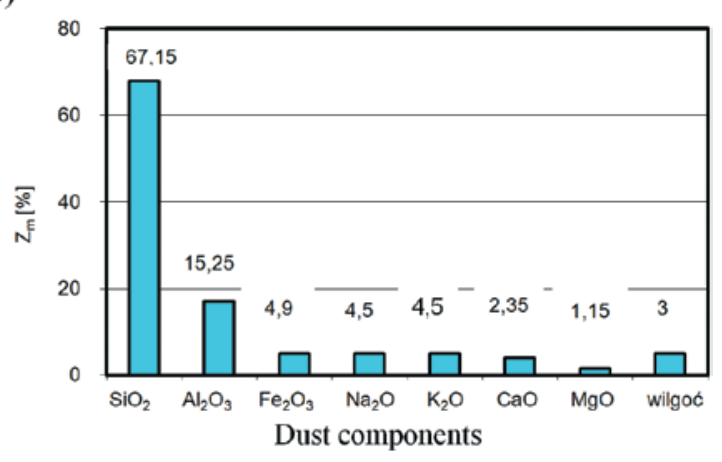

loading at the multi-cyclone inlet $s=1 \mathrm{~g} / \mathrm{m}^{3}$, and in a single-stage filtration system at dust loading $s=0.5 \mathrm{~g} / \mathrm{m}^{3}$, using PTC-D test dust corresponding to AC-Fine test dust, with size distribution and chemical composition detailed in Fig. 4.

Filter separation efficiency $\varphi_{w}$ in tested non-woven fabric filters was determined using mass method at subsequent $j$ cycles, with duration (uniform batching and distribution of test dust) at: $t_{\text {lpom }}=3 \mathrm{~min}$ - in the initial period i $t_{2 p o m}=15 \mathrm{~min}-$ in further testing period. Filter separation efficiency $\varphi_{w}$ of the tested filter element was determined after each $j$ cycle:

- separation efficiency $\varphi_{w}$ :

$$
\varphi_{w j}=\frac{m_{w j}}{m_{D j}} \cdot 100 \%,
$$

where: $m_{w j}-$ mass of dust retained by filter element, $m_{D j}-$ mass of dust introduced to the filter element (mass of dust at the multi-cyclone outlet) during the cycle:

$$
m_{D j}=m_{w j}+m_{A G j}
$$

where: $m_{A G}-$ mass of dust retained by absolute filter,

- flow resistance:

$$
\Delta \mathrm{pwj}=\frac{\Delta h_{w j}}{1000}\left(\rho_{m}-\rho_{H}\right) g[\mathrm{kPa}],
$$

where: $\Delta h_{w}$ - static pressure drop (in $\mathrm{mm}_{2} \mathrm{O}$ ) at U-tube water manometer, $\rho_{m}$ - manometer liquid density $\left(\mathrm{H}_{2} \mathrm{O}\right)$ at measurement temperature $t_{H}, \rho_{H}$ free air density in $\mathrm{kg} / \mathrm{m}^{3}, g$ - local acceleration of gravity.

- dust capacity $k_{m(1-j)}$ :

$$
k_{m(1-j)}=\frac{m_{w(1-j)}}{F_{w}}\left[\mathrm{~g} / \mathrm{m}^{2}\right]
$$

where: $m_{w(1-j)}$ - total mass of dust retained by filter element,

The tests were completed after the tested filter element reached the flow resistance of $5 \mathrm{kPa}$, which is the commonly used permissible flow resistance for air filters used in motor vehicles.

Filter element tests were carried out on a test stand (Fig. 5) for testing basic characteristics of separation efficiency and flow resistance for air flow rate up to $1500 \mathrm{~m}^{3} / \mathrm{h}$ at ejector suction rate up to $20 \%$ and dust loading up to $3 \mathrm{~g} / \mathrm{m}^{3}$.

A measuring line was installed directly downstream of the filter element, from which the end of the U-tube water manometer was connected in the distance of $6 D_{w}$ from the face of a filter element enclosure (where $D_{w}$-inner diameter of the outlet line from the tested paper filter element) to measure flow resistance $\Delta p_{w}$ (static pressure drop) at the filter element.

The measuring line ends with a filter protecting the measuring orifice plate against dust ingress, which is also a measuring filter to determine the mass of dust flowing through the tested filter element and as a consequence to determine the filter separation efficiency.

Fig. 4. PTC-D test dust used for testing: a) size distribution, b) chemical composition [27] 


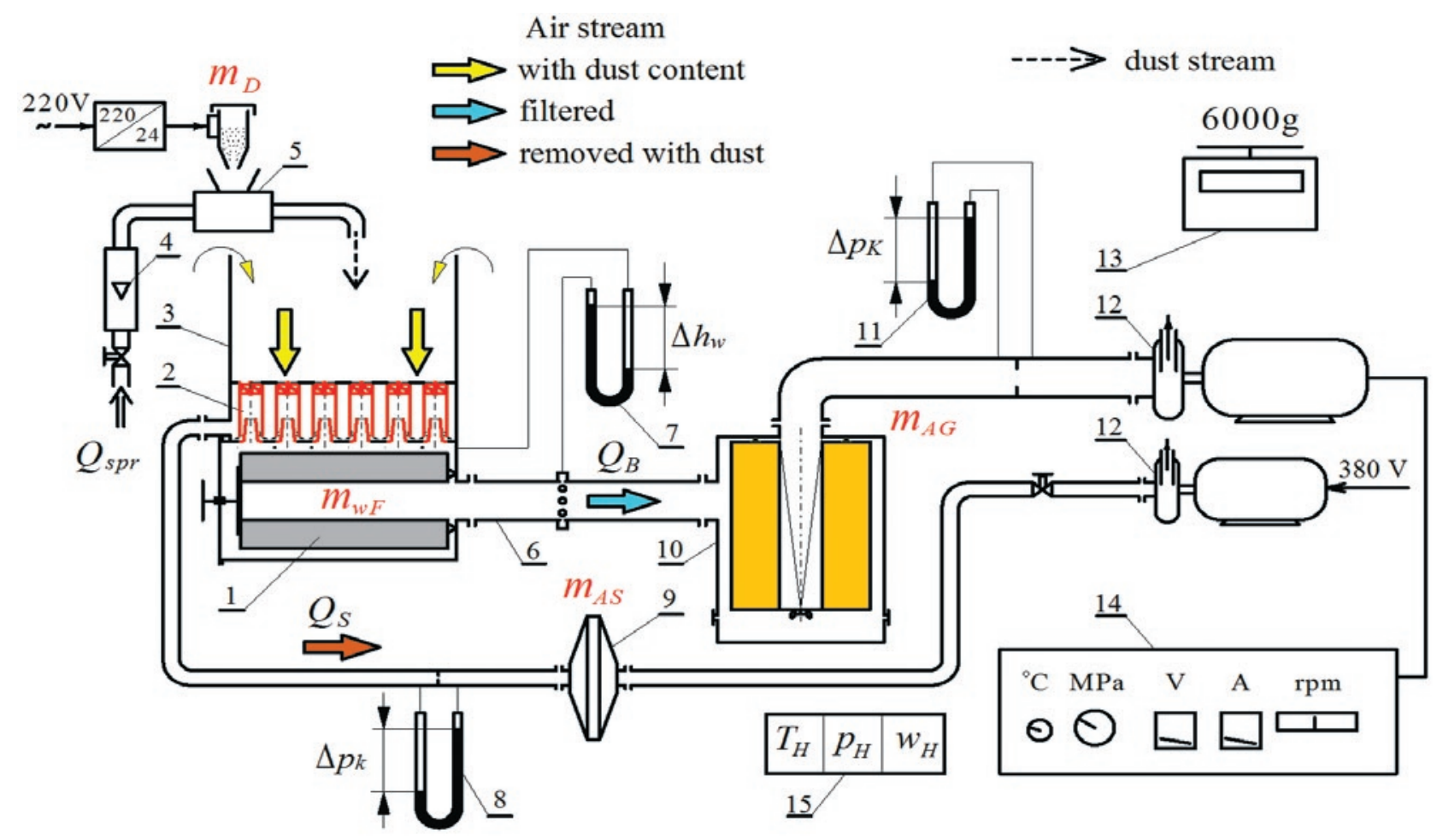

Fig. 5. Test stand diagram: 1 -tested filter element, 2 -dust collector, 3 -dust chamber, 4 -compressed air stream rotameter, 5 -dust feeder, 6 -flow resistance test line, 7 - static pressure drop manometer, filter element, 8 -differential manometer, measuring orifice plate (volume flow rate $\left.Q_{S}\right), 9$ - absolute filter, dust suction line, 10 - absolute filter, main line, 11 - differential manometer, measuring orifice plate $\left(Q_{G}\right.$ stream), 12 - suction fans, 13 - weight, 14 - engine and air fan control panel, 15 - pressure, temperature and relative humidity measuring unit

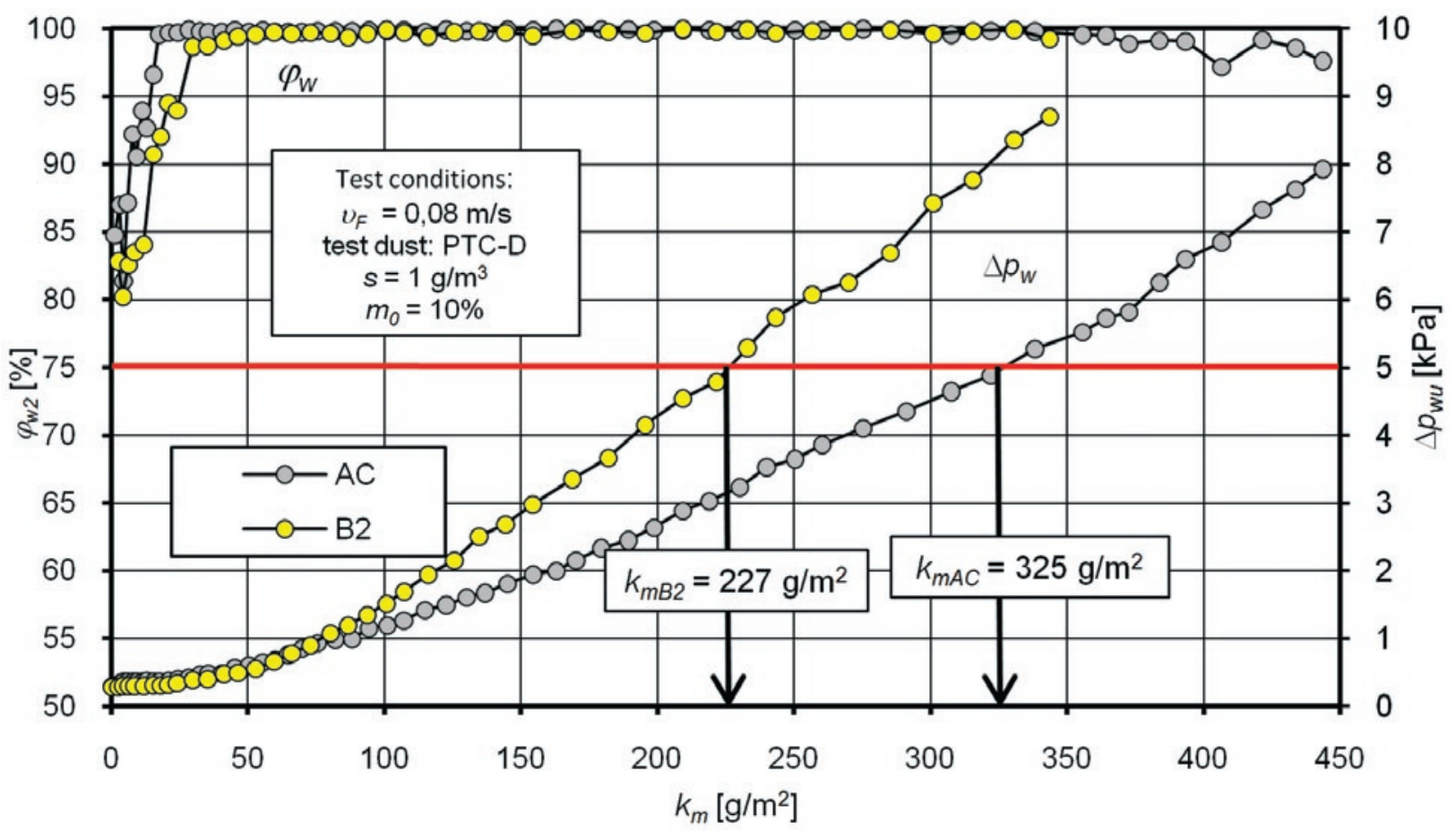

Fig. 6. Characteristics of the filter separation efficiency $\varphi_{w}$ and flow resistance $\Delta p_{w}$ as a function of dust capacity $k_{m}$ of systems made of $A C$ and $B 2$ non-woven fabric filters in "multi-cyclone - non-woven fabric panel filter" configuration

\section{Test result analysis}

Fig. 6 shows filter separation efficiency and flow resistance of filter elements made of AC and B2 non-woven fabrics in two-stage filtration system downstream of the multi-cyclone as a function of dust capacity. Due to the achieved filter separation efficiency, operation time of tested non-woven fabrics can be divided into two periods. The first (initial) period characterized by low filter separation efficiency, which systematically and rapidly increases with the quantity of dust mass retained by the filter paper. The period lasts from the moment the filtration process commences until the specific filter separation 


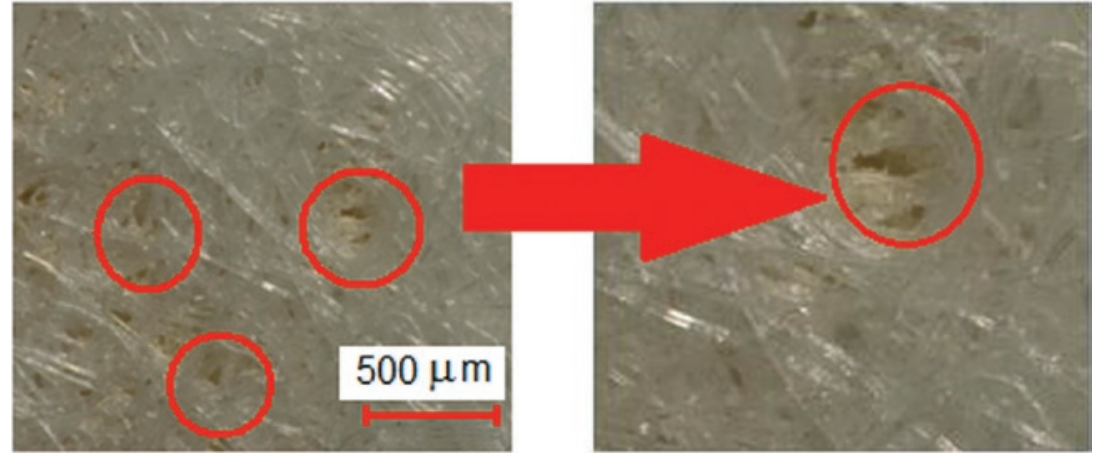

Fig. 7. Visible punctures in non-woven fabric

efficiency is reached by the non-woven fabric. The following main filtration period is characterized by high (over 99\%), continuously and slowly increasing filter separation efficiency. In case of tested non-woven fabrics, the interface of both periods was defined as the moment the filter separation efficiency reached 99.5\% [8]. After the first measuring cycle, the filter separation efficiency of AC non-woven fabric reached $\varphi_{w 2}=84.8 \%$, and B2 non-woven fabric reached $\varphi_{w 2}=80.2 \%$ (Fig. 4). The first filtration period (anticipated filter separation efficiency $\varphi_{w}=99.5 \%$ ) for non-woven fabric AC lasted until the dust capacity $k_{m 2}=17,3 \mathrm{~g} / \mathrm{m}^{2}$ was reached For B2 non-woven fabric, the duration of the period was almost twice longer and lasted until the dust capacity of $k_{m 2}=35.4 \mathrm{~g} / \mathrm{m}^{2}$ was reached.

The initial operation period of the non-woven fabric filter is very adverse for two mating parts, since at the same time, a significant quantity of dust with particle size $d_{z}=(2 \div 5) \mu \mathrm{m}$ is introduced to the engine cylinders with air [10]. It may result in premature wear of mating engine parts. New installed non-woven fabric filter element (paper) will not provide the required separation efficiency and filtration rate until a specific mileage. Frequent and unnecessary replacement of the filter element should be avoided.

In the main filtration period, the filter separation efficiency of tested non-woven fabrics is $\varphi_{w 2}=(99.5 \div 99.97) \%$. High AC nonwoven fabric filter separation efficiency is maintained until the dust capacity of $k_{m 2}=364 \mathrm{~g} / \mathrm{m}^{2}$ is reached. A decrease in filter separa- tion efficiency to the value of $(97 \div 98) \%$ can be observed in a single measuring point beyond this value, which may indicate depletion of filter medium capacity and/or puncture. Large dust particles and clusters are captured as a result of high flow rate and high pressure difference upstream and downstream of the filter element and forced inside the medium to the outlet side of the filter medium. Fig. 7 shows example points, where the dust was forced through the filter medium. In case of B2 non-woven fabric, the decrease in filter separation efficiency occurred slightly earlier at the dust capacity of $k_{m 2}=343 \mathrm{~g} / \mathrm{m}^{2}$.

With the increase in mass of dust retained by the non-woven fabric filter, the flow resistance of the filter element systematically increases, although the intensity of the increase is higher for the element made of B2 non-woven fabric. After reaching the permissible flow resistance $\Delta p_{w}=5 \mathrm{kPa}$, the dust capacity of AC non-woven fabric is $k_{m 2}=325 \mathrm{~g} / \mathrm{m}^{2}$, and significantly lower in case of B2 non-woven fabric at $k_{m 2}=227 \mathrm{~g} / \mathrm{m}^{2}$ due to lower mass of dust retained by the fabric. It can be explained by lower thickness of B2 non-woven fabric, and thus lower dust capacity. The dust capacity of paper filters in two-stage filtration systems is significantly lower $\left(k_{m}=50 \div 80 \mathrm{~g} / \mathrm{m}^{2}\right)$ compared to tested non-woven fabrics.

Fig. 8 shows comparative analysis of AC non-woven fabric filter performance in the single and two-stage system in "multi-cyclone non-woven fabric panel filter" configuration. Filter separation efficiency and flow resistance of the non-woven fabric filter element in the single-stage filtration system (standard particle size distribution) increases with lower intensity compared to the filter element made of the same AC non-woven fabric in the "multi-cyclone - non-woven fabric panel filter" configuration. It is due to the fact, that the dust downstream of the cyclone does not contain particles $>(20 \div 35) \mu \mathrm{m}$, due to the filtration rate of the mini-cyclones [1, 10, 17, 22]. The filter element is affected by smaller dust particles, which fill all the areas between the fibres, increasing the flow rate and thus intensifying the flow resistance.

Permissible flow resistance $\Delta p_{w}=5 \mathrm{kPa}$ was reached by the nonwoven fabric filter in the single-stage filtration system at the dust capacity of $k_{m l}=700 \mathrm{~g} / \mathrm{m}^{2}$, and thus at twice the value compared to

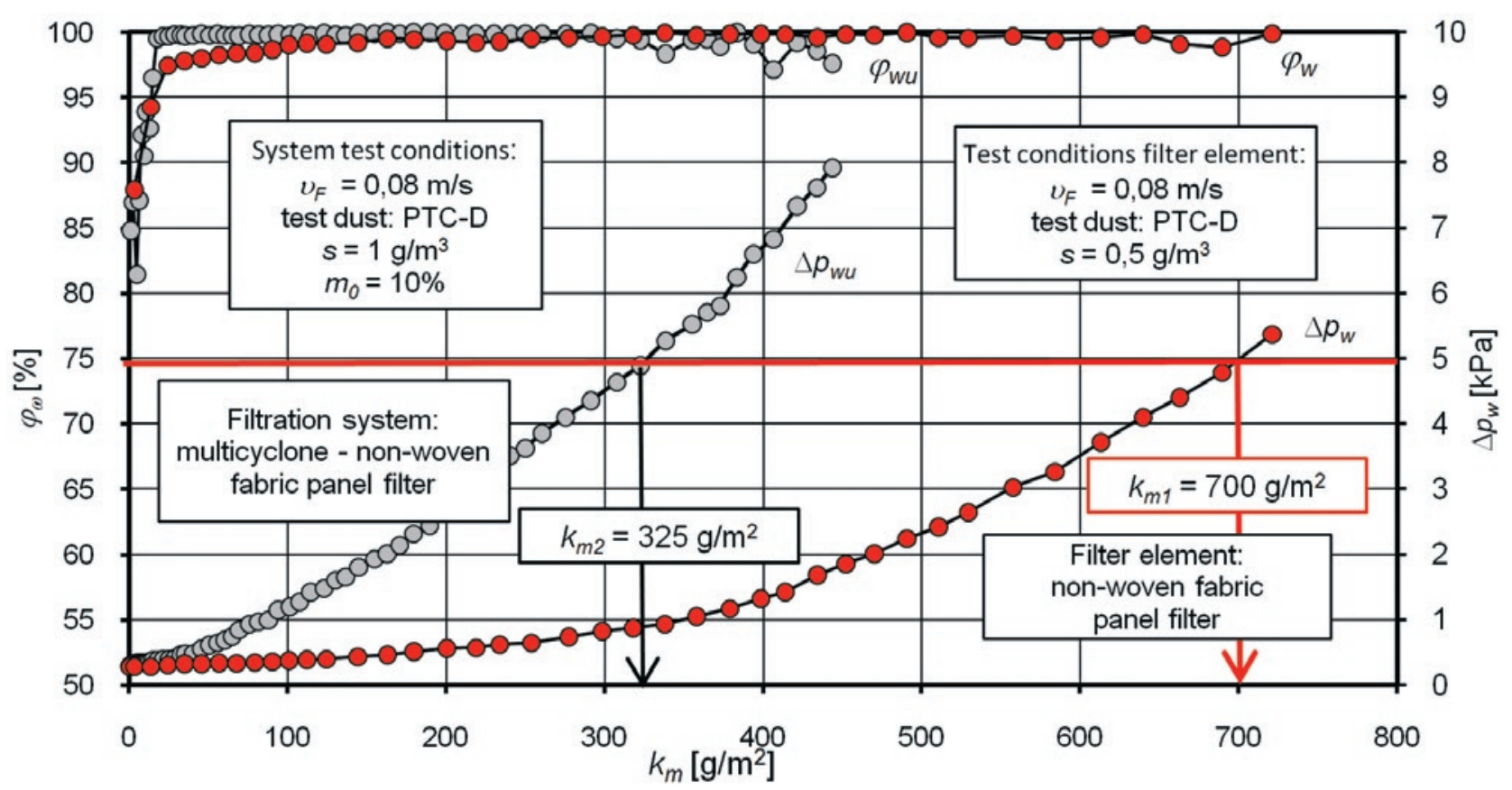

Fig. 8. Characteristic curves of filter separation efficiency $\varphi_{w}$ and flow resistance $\Delta p_{w}$ of AC-301 non-woven fabric filters in single and two-stage filtration system in "multi-cyclone-non-woven fabric panel filter" configuration 


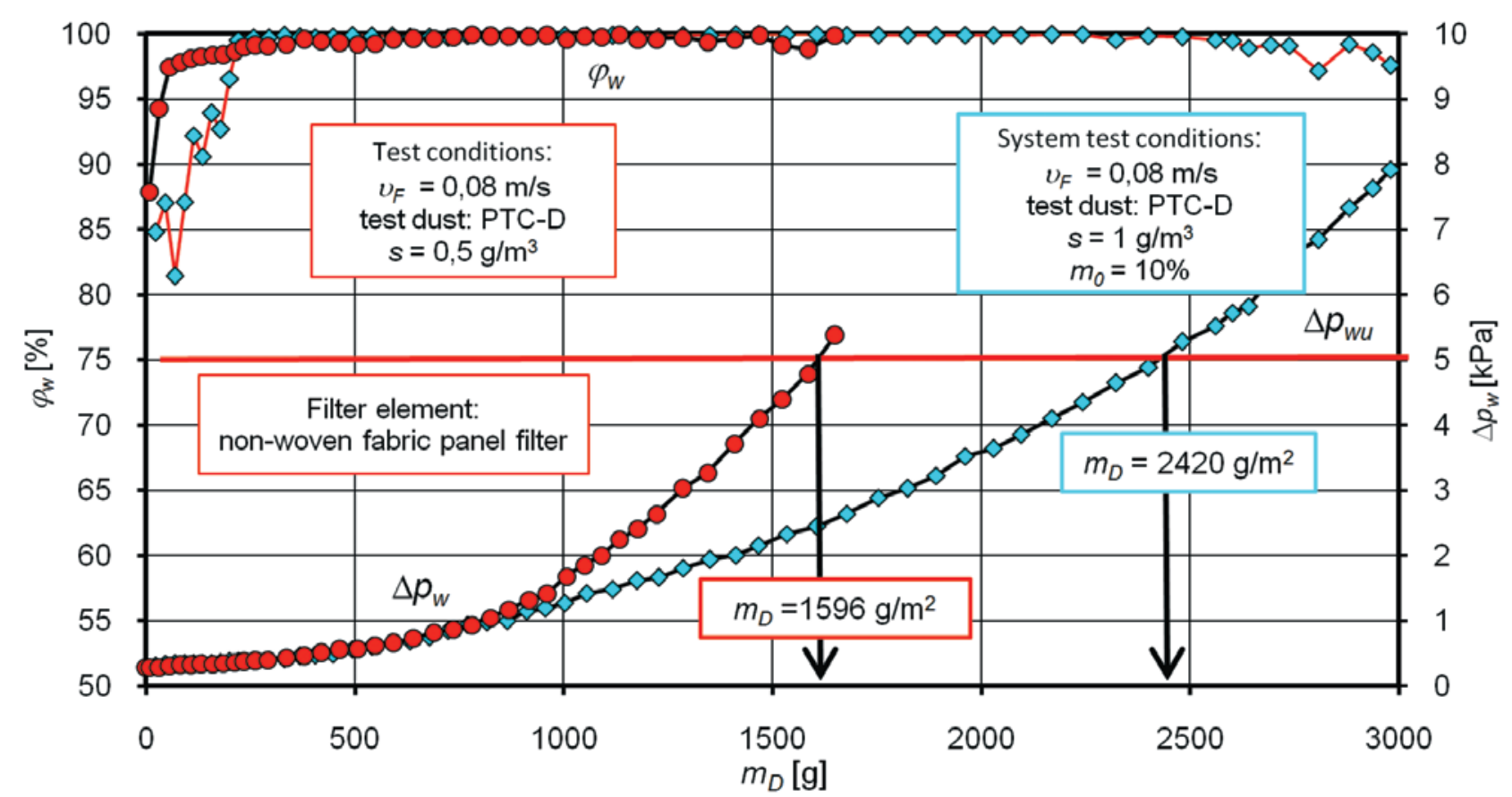

Fig. 9. Characteristics of filter separation efficiency $\varphi_{w}$ and flow resistance $\Delta p_{w}$ of AC-301 non-woven fabric filters in single and two-stage filtration system in "multi-cyclone-non-woven fabric panel filter" configuration as a function of dust mass $m D$ introduced to the filter

two-stage filtration system $-k_{m 2}=325 \mathrm{~g} / \mathrm{m}^{2}$. The dust capacity of the non-woven fabric subject to dust with size distribution changed by the inertia filter $\left(d_{z}<20 \div 35 \mu \mathrm{m}\right)$ is lower than the dust capacity of the non-woven fabric subject to the external dust $\left(d_{z}<80 \mu \mathrm{m}\right)$ by $50 \%$. It is consistent with the data available in the studies on filter paper testing $[10,14]$.

Lower dust capacity of the non-woven fabric subject to dust with size distribution changed by the inertia filter does not mean reduced service life of the two-stage filtration system (shorter mileage) until the permissible flow resistance $\Delta p_{f d o p}$. is reached. Although more dust (Fig. 9) is introduced with the air to the system, service life of the two-stage filtration system in "multi-cyclone-non-woven fabric panel filter" configuration $\tau_{p 2}$ is significantly longer. Service life can be calculated from the following equation [1]:

$$
\tau_{p 2}=\frac{F_{c} \cdot k_{m 2} \cdot k_{c}}{Q_{S i l \max } \cdot s \cdot\left(1-\varphi_{M}\right) \cdot \varphi_{w}}
$$

where: $F_{c}$ - total surface area, second stage filtration, $k_{m 2}$ - dust capacity of non-woven fabric, $k_{c}$ - coefficient allowing for the difference between test and actual dust parameters, $Q_{\max }-$ volume flow rate via engine, $s$ - average dust loading in drawn in air, $\varphi_{M}$ - first stage filter separation efficiency (multi-cyclone), $\varphi_{w}$ - filter separation efficiency of non-woven fabric filter.

For the following data: $F_{c}-2 \mathrm{~m}^{2}, k_{m 2}-325 \mathrm{~g} / \mathrm{m}^{2} ; k_{c}-1$; $Q_{\max }-600 \mathrm{~m}^{3} / \mathrm{h} ; s-1 \mathrm{~g} / \mathrm{m}^{3} ; \varphi_{M}=0.8 ; \varphi_{w}=0.99$; service time of twostage filtration system is $\tau_{p 2}=5.47 \mathrm{~h}$. For the same non-woven fabric in single-stage filtration system, the filter achieves $\tau_{p 2}=2.37 \mathrm{~h}$, which is half the value compared to the data in Fig. 3.

\section{Summary}

Non-woven fabrics are more and more commonly used in the inlet air filter systems of modern passenger vehicles. However, no data are available on use of non-woven fabrics as a second filtration stage in multi-stage filters used in trucks and special vehicles, mostly due to the unknown operational properties of non-woven fabric filters, in particular dust capacity. Dust capacity values for non-woven fabrics used as the second filtration stage (downstream of the inertia filter) are lower compared to non-woven fabrics used in single-stage filtration systems. It directly affects the filter service life (time until it reaches permissible flow resistance) and thus vehicle mileage.

The tests of two non-woven fabric filters: AC-301 and BWF 02 E200B in two-stage filtration system downstream of the multicyclone have shown that the dust capacity at determined flow resistance $\Delta p_{\text {fdop }}=5 \mathrm{kPa}$ varies, depending on the parameters of non-woven fabric structure and is $k_{m 2}=325 \mathrm{~g} / \mathrm{m}^{2}$ and $k_{m 2}=227 \mathrm{~g} / \mathrm{m}^{2}$, respectively. At identical permissible flow resistance, filter papers used as the second filtration stage downstream of the cyclone, achieve the dust capacity of $k_{m 2}=(50 \div 80) \mathrm{g} / \mathrm{m}^{2}$ [9] which is several times lower due to the lower thickness of the filter paper.

The tests of AC-301 non-woven fabric filter in single-stage filtration system (PTC-D test dust, standard size distribution up to $d_{z}<80 \mu \mathrm{m}$ ) have shown that the characteristics of the flow resistance $\Delta p_{w}=f\left(k_{m}\right)$ vary. Significantly lower intensities of the increase in flow resistance of the non-woven fabric subject to test dust with standard size distribution compared to the non-woven fabric subject to dust from the multi-cyclone (significantly smaller particle size) have been observed.

(Fig. 9). The dust capacity determined for AC-301 non-woven fabric at specific conditions and flow resistance $\Delta p_{\text {fdop }}=5 \mathrm{kPa}$ was $k_{m 1}=700 \mathrm{~g} / \mathrm{m}^{2}$, almost twice as high as achieved in the two-stage filtration system.

Actual service life of the two-stage filter, with a filter medium designed using dust capacity $k_{m l}$ resulting from the non-woven fabric operation in the single-stage filtration system, which is often used when designing filter paper elements, will be halved.

Low $\left(\varphi_{w 2}=(80 \div 84) \%\right)$ filter separation efficiency and presence of large dust particles in the air in the initial, however short operation period may result in a premature wear of mating parts, in particular piston, rings and cylinder. In actual operating conditions, the initial operation period occurs after replacement of the old filter element with a new one.

The filter reaches its highest filter separation efficiency (99.9\%) in the end period, when the flow resistance is close to the permis- 
sible flow resistance, which is also a criterion for the filter element change. Since high filter separation efficiency is a much-desired property, filter elements should be used as long as possible. An increase in the mass of dust retained at the filter element, not only increases its separation efficiency but also its flow resistance, which in turn may affect motor power and fuel consumption. The manufacturers of modern passenger vehicles recommend filter element change after a specific mileage $((30 \div 60)$ thousand kilometres $)$ and/or based on the flow resistance indication.

\section{References}

1. Baczewski K, Hebda M. Filtracja płynów eksploatacyjnych. Radom: MCNEMT, 1991/92.

2. Barbolini M, Di Pauli F, Traina M. Simulation der Luftfiltration zur Auslegung von Filterelementen. MTZ 2014; 11: 53-56, http://dx.doi. org/10.1007/s35146-014-0556-5.

3. Calculating Engine Airflow. www.donaldson.com

4. Chłopek Z. Testing of hazards to the environment caused by particulate matter during use of vehicles. Eksploatacja i Niezawodnosc Maintenance and Reliability 2012; 2: 160-170.

5. Chłopek Z, Jakubowski A. The examination of the reduction of particulate matter emission from motor vehicle braking system. Eksploatacja i Niezawodnosc - Maintenance and Reliability 2010; 4: 39-36.

6. Das A, Alagirusamy R, Nagendra K R. Filtration characteristics of spun-laid nonwoven fabrics, Indian Journal of Fibre \& Textile Research 2009; 34: 253-257.

7. Duchowski J, Collins K. Cleanlines Requirements for Journal Bearing Lubrication. Practicing Oil Analysis Magazine $2000 ; 7$.

8. Durst M, Klein G, Moser N. Filtration in Fahrzeugen. Ludwigsburg: Mann+Hummel GMBH, 2005.

9. Dziubak T. The test stand of air tillers cyclones of vehicles operating in high dustiness condition. Eksploatacja i Niezawodnosc - Maintenance and Reliability 2003; 4: 31-46.

10. Dziubak T, Szwedkowicz S. Experimental research on filtering fibers in a cyclone-porous barrier system. Combustion Engines 2014 ; 3: 45-55.

11. Extreme Performance Air Filters with ProTura Nanofiber Technology, Kearney: Baldwin Filters, 2014.

12. Fitch J. Clean Oil Reduces Engine Fuel Consumption. Practicing Oil Analysis Magazine 2005; 9.

13. Golloch R, Kessen U, Merker G P. Tribologische Untersuchungen an der Kolbengruppe eines NFZ-Dieselmotors. MTZ 2002; 6: 494-501, http://dx.doi.org/10.1007/bf03226635.

14. Heavy-Duty Air Filter Media Applications. East Walpole: Holingsworth \& Vose, 2011.

15. Jaroszczyk T, Fallon S. L, Janikowski E, Kendall O D. Nanofiber Media Performance in Aplication to Motor Vehicle Air Filtration. Nanofibers for the 3td Millennium - Nano for Life. Praga, 2009.

16. Jaroszczyk T. Air Filtration in Heavy-Duty Motor Vehicle Applications. Proc. Dust Symposium III Vicksburg MS, September 15-17. 1987.

17. Jo Y, Tien Ch, Ray M B. Development of a post cyclone to improve the efficiency of reverse flow cyclone. Powder Technology 2000; 1-2: 97-108, http://dx.doi.org/10.1016/S0032-5910(00)00206-0.

18. Koszałka G, Niewczas A. Wear profile of the cylinder liner in a motor truck diesel engine. Journal of KONES 2007; 4: 183-190.

19. Koszałka G. Predicting the durability of the piston-rings-cylinder, assembly of a diesel engine using a piston ring pack model. Eksploatacja i Niezawodnosc - Maintenance and Reliability 2011;. 3: 40-44.

20. Коренев М С, Рузаев И Г. Фильтровальный материал из синтетических волокон для воздухоочистителей. Автомобильная промышленность 1982; 9.

21. Kothari V. K, Das A, Singh S. Filtration behavior of woven and nonwoven fabrics. Indian Journal of Fibre \& Textile Research 2007; 32: 214-220.

22. Lim K S, Kim H S, Lee K W. Characteristics of the collection efficiency for a cyclone with diffirent vortex finder shapes. Journal of Aerosol Science 2004; 6: 743-754, http://dx.doi.org/10.1016/j.jaerosci.2003.12.002

23. Merkisz J, Lijewski P, Fuć P, Weymann S. Exhaust emission tests from non-road vehicles conducted with the use of PEMS analyzers. Eksploatacja i Niezawodnosc - Maintenance and Reliability 2013; 4: 364-368.

24. Muller T K, Meyer J, Thebault E, Kasper G. Impact of an oil coating on particle deposition and dust holding capacity of fibrous filters. Powder Technology 2014; 253: 247-255, http://dx.doi.org/10.1016/j.powtec.2013.11.036.

25. Muller T K, Meyer J, Thebault E, Kasper G. Dust capacity increase of air filters by oil pre-treatment. Aerosol Technology 2014.

26. Niewczas A, Wrona J, Wrona R. Zanieczyszczenia oleju smarującego oraz ich wpływ na trwałość silnika spalinowego. Autobusy: technika, eksploatacja, systemy transportowe 2010; 6: 1-5.

27. PN-S-34040, Filtry powietrza. Wymagania i badania. PKN, 1996.

28. Sakthivel S, Ehzil Anban J J, Ramachandran T.: Development of Needle-Punched Nonwoven Fabrics from Reclaimed Fibers for Air Filtration Applications. Journal of Engineered Fibers and Fabrics 2014; 9: 149-154.

29. WIX Filtron, materiały udostępnione przez Filtron, Gostyń, 2013.

30. www.retopfibre.en.alibaba.

Tadeusz DZIUBAK

Sebastian SZWEDKOWICZ

Military University of Technology

Faculty of Mechanical Engineering

ul. Gen. Sylwestra Kaliskiego 2

0-908 Warszawa, Poland

E-mail: tdziubak@wat.edu.pl,sszwedkowicz@wat.edu.pl 